\title{
Postępowania prekwalifikacyjne jako pierwszy etap udziału w aukcjach OZE
}

\section{Wprowadzenie}

Jednym z podsektorów energetyki o największej perspektywie rozwoju jest wytwarzanie energii elektrycznej opartej na wykorzystaniu różnego rodzaju odnawialnych źródeł energii (OZE). Innowacje technologiczne umożliwiające wykorzystywanie odnawialnych sił przyrody do produkcji energii stały się też przedmiotem szczegółowych regulacji prawnych kształtujących zasady prowadzenia tego typu działalności gospodarczej. W związku z powyższym zarówno prawodawca europejski, jak i polski ustawodawca dostrzegli konieczność systemowego ${ }^{1}$ wspierania rozwoju OZE, upatrując w nich potencjał do zrównoważonego rozwoju gospodarki. Wsparcie to realizowane jest w szczególności poprzez prawne instrumenty stanowiące pomoc publiczną ${ }^{2}$, która musi być zgodna $z$ regułami konkurencji UE. W polskim systemie prawnym podstawowym aktem normatywnym określającym mechanizmy i instrumenty wspierające wytwarzanie energii elektrycznej z OZE jest obowiązująca

${ }^{1}$ Na konieczność zastosowania przemyślanej strategii publicznego wsparcia inwestycji w zakresie OZE wskazują: T. Henzelmann, P. Hoff, Zielone finansowanie i nowe "zielone złoto", w: Zielony wzrost, zielony zysk. Jak zielona rewolucja stymuluje gospodarke, pod red. R. Berger, Warszawa 2014, s. 280-285.

${ }^{2}$ Szerzej zob. D. Kobiałko, Analiza ustawy o odnawialnych źródłach energii z 20 lutego 2015 roku w świetle przepisów unijnych dotyczących pomocy publicznej, "Przegląd Prawniczy Europejskiego Stowarzyszenia Studentów Prawa ELSA Poland" 2015, z. III, s. 167-183; W. Szopiński, Czy systemy wsparcia dla energii z odnawialnych źródeł przewidziane w projekcie ustawy o odnawialnych źródłach energii można uznać za pomoc publiczną?, "Przegląd Prawniczy Europejskiego Stowarzyszenia Studentów Prawa ELSA Poland" 2015, z. III, s. 153-166. 
od niedawna Ustawa z dnia 20 lutego 2015 r. o odnawialnych źródłach energii ${ }^{3}$. Ustawa ta zrewolucjonizowała dotychczasowy system wspierania OZE uregulowany w Ustawie z dnia 10 kwietnia 1997 r. - Prawo energetyczne ${ }^{4}$, zastępując dotychczasowy system świadectw pochodzenia, tzw. zielonych certyfikatów, rekomendowanym przez prawodawstwo unijne systemem aukcji OZE 5 . System świadectw pochodzenia został utrzymany dla wytwórców, którzy wytworzyli energię elektryczną przed dniem 1 lipca 2016 r., i będzie stopniowo wygaszany. Natomiast wszyscy nowi wytwórcy, którzy uruchomią swoje instalacje OZE po tej dacie, będą mieli szansę wzięcia udziału w aukcji OZE, z wyłączeniem prosumentów, dla których ustawodawca stworzył odrębne instrumenty wsparcia ${ }^{6}$.

Nie wchodząc na razie w szczegóły, należy wskazać, że w rozdziale 4 u.o.z.e. zatytułowanym „Mechanizmy i instrumenty wspierające wytwarzanie energii elektrycznej z odnawialnych źródeł energii, biogazu rolniczego oraz ciepła, w instalacjach odnawialnego źródła energii" (art. 39 i n. u.o.z.e.) ustawodawca wskazal, że docelowym modelem wsparcia OZE będzie system aukcyjny ${ }^{7}$, który będzie obowiązywał do dnia 31 grudnia 2035 r., a w przypadku morskich farm wiatrowych aż do 31 grudnia 2040 r. Jak podkreślono w uzasadnieniu do u.o.z.e. , celem wprowadzenia systemu aukcyjnego jest wytworzenie w sposób jak najbardziej efektywny kosztowo określonego wolumenu energii ze źródeł odnawialnych, w ramach nałożonych na Polskę zobowiązań wynikających z polityki klimatyczno-energetycznej UE. Oznacza to, że w drodze konkurencyjnej aukcji, organizowanej przez Prezesa Urzędu

${ }^{3}$ Dz.U. 2015, poz. 478, dalej „u.o.z.e.".

4 Tekst jedn. Dz.U. 2017, poz. 220, dalej „u.p.e.”.

${ }^{5}$ Zob. Komunikat Komisji Europejskiej - Wytyczne w sprawie pomocy państwa na ochronę środowiska i cele związane z energią w latach 2014-2020 (Dz.Urz. UE C 200 z 28 VI 2014 r., s. 1).

${ }^{6}$ I. Szwedziak-Bork, Ile konsumenta w prosumencie w świetle ustawy o odnawialnych źódłach energii?, w: Prawo konsumenckie w praktyce, pod red. M. Czarneckiej, T. Skocznego, Warszawa 2016, s. 262-273; A. Wlazły, Energetyka prosumencka. Zachowania prosumentów w sektorze energetycznym, w: Prawo konsumenckie..., s. 274-286.

${ }^{7}$ Zob. A. Bohdan, M. Przybylska, Podstawy prawne OZE (odnawialnych źródeł energii) i gospodarki odpadami w Polsce, Warszawa 2015, s. 55-56; T. Długosz, Aukcja na sprzedaż energii elektrycznej wytwarzanej z odnawialnych źródeł energii wytworzonej w instalacjach odnawialnego źródła energii - nowy środek wspierajacy wybrany sektor gospodarki, w: Prawne instrumenty oddziaływania na gospodarke, pod red. A. Powałowskiego, Warszawa 2016, s. $431-439$.

${ }^{8}$ Zob. uzasadnienie projektu ustawy - http://www.sejm.gov.pl/Sejm7.nsf/druk. xsp?nr=2604 (dostęp: 23 XI 2016). 
Regulacji Energetyki (dalej „Prezes URE”) zostaną wyłonieni wytwórcy energii z instalacji OZE, którzy zostaną objęci przewidzianym przez ustawodawcę systemem wsparcia, gwarantującym uzyskanie wylicytowanej w ramach aukcji ceny sprzedaży energii elektrycznej, zapewniającej operacyjne wsparcie prowadzonej działalności gospodarczej. Podstawowym kryterium wygrania danej aukcji OZE, w ramach przewidzianych przez Radę Ministrów maksymalnych limitów ${ }^{9}$ dla poszczególnych koszyków technologicznych, jest cena sprzedaży, po której wytwórcy gotowi są wytwarzać tę energię w instalacjach OZE charakteryzujących się odpowiednimi parametrami technicznymi. Zaproponowana przez wytwórców cena tejże energii jest jednym z podstawowych elementów złożenia konkurencyjnej względem pozostałych uczestników oferty, szczegółowo opisanej w art. 79 u.o.z.e. Warto też podkreślić, że zaproponowana w ofercie cena aukcyjna nie może przekraczać poziomu ceny referencyjnej, określającej maksymalny poziom ceny za $1 \mathrm{MWh}$ wytworzonej w każdej z technologii OZE. Szczegółowe uregulowania w tym zakresie określa Rozporządzenie Ministra Energii z dnia 17 października 2016 r. w sprawie ceny referencyjnej energii elektrycznej z odnawialnych źródeł energii w 2016 r. oraz okresów obowiązujących wytwórców, którzy wygrali aukcje w 2016 r. ${ }^{10}$ Odpowiednie rozporządzenia dotyczące wolumenu energii przeznaczanej na aukcję OZE (tzw. rozporządzenia wolumenowe) oraz rozporządzenia dotyczące poziomu cen referencyjnych będą wydawane przez określone organy administracji na każdy rok, w którym planowane będzie przeprowadzenie aukcji OZE. Jednakże prawidłowe skonstruowanie konkurencyjnej cenowo oferty nie jest jedynym warunkiem pozytywnego rozstrzygnięcia w ramach systemu aukcyjnego. Warto też wskazać, że etap złożenia skalkulowanej przez wytwórcę oferty poprzedzony jest odpowiednią procedurą wstępnej oceny formalnej, umożliwiającej faktyczne dopuszczenie danego wytwórcy do udziału w aukcji OZE. W art. 75 ust. 1 u.o.z.e. ustawodawca expressis verbis wskazuje, że wytwórca, który zamierza przystąpić do aukcji, podlega procedurze oceny formalnej przygotowania do wytwarzania energii elektrycznej w danej instalacji OZE. W doktrynalnym ujęciu postępowania te można określić mianem postępowań prekwalifikacyjnych, mających na celu sprawdzenie przez Prezesa URE wskazanych

${ }^{9}$ Zob. Rozporządzenie Rady Ministrów z dnia 27 X 2016 r. w sprawie maksymalnej ilości i wartości energii elektrycznej z odnawialnych źródeł energii, która może być sprzedana w drodze aukcji w 2016 r. (Dz.U. 2016, poz. 1846).

10 Dz.U. 2016, poz. 1765. 
przez ustawodawcę dokumentów inwestycyjnych, na podstawie których będzie funkcjonować instalacja OZE zgłaszana do aukcji OZE. W związku z powyższym prawidłowe przejście owej procedury warunkuje możliwość złożenia oferty aukcyjnej przez danego wytwórcę. Ostatecznie, biorąc pod uwagę wskazane powyżej rozważania, łatwo wyobrazić sobie sytuację, w której przygotowany przez wytwórcę projekt inwestycji w instalację OZE jest znakomicie skalkulowany pod względem ekonomicznym i ze względu na zaproponowaną cenę sprzedaży tejże energii ma bardzo dużą szansę na uzyskanie wsparcia w ramach aukcji, jednakże projekt ten nie może być ostatecznie zrealizowany wskutek nieprawidłowości na etapie wstępnej procedury dopuszczenia do udziału w aukcji OZE. W dalszej części niniejszego opracowania wskazane zostaną podstawowe cele przeprowadzania owych postępowań prekwalifikacyjnych, a ponadto szerszej analizie prawnej zostaną poddane szczegółowe przepisy u.o.z.e. konstytuujące ten obowiązek tak, aby każdy zainteresowany udziałem w danej aukcji podmiot mógł skutecznie przygotować się do złożenia oferty aukcyjnej.

\section{Cele przeprowadzenia postępowań prekwalifikacyjnych w ramach aukcji OZE}

Tak jak już wskazano, ustawodawca nie tylko oparł nowy system wspierania OZE na systemie aukcyjnym, ale też uzależnił możliwość przystąpienia do aukcji OZE od konieczności przeprowadzenia odpowiednich procedur formalnoprawnych, umożliwiających danemu podmiotowi uczestnictwo w takiej aukcji. Biorąc pod uwagę to, że przepisy u.o.z.e. zmieniają dotychczasowy system wspierania instalacji OZE uregulowany w przepisach u.p.e., wydaje się, iż podstawowym celem ustawodawcy w tym zakresie była chęć przeprowadzenia swego rodzaju audytu prawnego poszczególnych instalacji OZE, które w dalszej perspektywie zamierzają wystartować w organizowanej przez Prezesa URE aukcji OZE. Wniosek ten jest uzasadniony w szczególności w przypadku, gdy do aukcji przygotowywane są nowe projekty instalacji OZE, które zostaną dopiero wybudowane po wygraniu przez danego wytwórcę aukcji OZE. Zgodnie bowiem z treścią art. 79 ust. 3 pkt 8 lit. a u.o.z.e. oferta złożona przez wytwórcę będącego uczestnikiem aukcji OZE musi zawierać stosowne zobowiązanie wytwórcy wskazujące, że do pierwszego wytworzenia energii elektrycznej z nowo projektowanej 
instalacji OZE dojdzie w terminie 48 miesięcy od dnia zamknięcia danej aukcji OZE. W dalszej części przepis ten określa dwa wyjątki od tej zasady, wskazując, że instalacje OZE wykorzystujące do produkcji energii elektrycznej promieniowanie słoneczne muszą wytworzyć tę energię w terminie 24 miesięcy od dnia zamknięcia aukcji, a w przypadku instalacji wykorzystujących siłę wiatru na morzu w terminie 72 miesięcy. Natomiast w stosunku do instalacji istniejących już przed dniem 1 lipca 2016 r. wiążący jest termin wskazany w art. 79 ust. 3 pkt 8 lit. b u.o.z.e. W przepisie tym wskazano, że istniejąca instalacja powinna rozpocząć wytwarzanie energii elektrycznej na podstawie wygranej aukcji OZE nie później niż pierwszego dnia miesiąca następującego po upływie miesiąca od miesiąca, w którym nastąpiło zamknięcie danej aukcji OZE. Niedotrzymanie powyższych terminów wiąże się nie tylko $z$ sankcją przewidzianą $w$ art. 83 ust. 3 u.o.z.e., ale może powodować także problemy $z$ dotrzymaniem zadeklarowanego wolumenu energii elektrycznej, który wytwórca zobowiązał się wytworzyć w ramach składanej oferty aukcyjnej. Tak więc realizacja postępowań prekwalifikacyjnych przede wszystkim zapewnić ma bezzwłoczne przystapienie do realizacji inwestycji zaraz po wygraniu aukcji OZE tak, aby w określonym powyżej terminie wytwórca energii z instalacji OZE mógł rozpocząć eksploatację urządzeń wytwórczych, a w konsekwencji wytworzyć po raz pierwszy energię elektryczną. W tym zakresie należy wskazać, że do pierwszego wytworzenia energii elektrycznej dochodzi już w momencie przeprowadzenia rozruchu technologicznego, którego podstawowym celem jest przeprowadzenie prób i testów urządzeń wytwórczych oraz instalacji wyprowadzających moc, w konsekwencji umożliwiających końcowy odbiór danej instalacji OZE ${ }^{11}$. Jednym z efektów przeprowadzenia takich prób i testów przyłączonej do sieci instalacji OZE jest wytworzenie po raz pierwszy energii elektrycznej. Zatem, jeżeli do przeprowadzenia rozruchu technologicznego zmierzającego do końcowego odbioru technicznego tej instalacji dochodzi w terminie 48 miesięcy od wygrania aukcji, a w trakcie tego rozruchu dojdzie do wytworzenia energii elektrycznej, to zachowane zostają terminy wskazane w art. 79 ust. 3 pkt 8 lit. a u.o.z.e. W związku z powyższym, przygotowując się do udziału w aukcji OZE, należy dysponować gotową dokumentacją inwestycyjną projektu, która umożliwia bezzwłoczne

${ }^{11}$ Por. definicję ustawową pojęcia "rozruch technologiczny", uregulowaną w art. 2 pkt 30 u.o.z.e. 
przystąpienie do budowy bądź uruchomienia instalacji OZE zaraz po wygraniu danej aukcji. W toku postępowania prekwalifikacyjnego Prezes URE w szczególności dokona analizy przedstawianych dokumentów, stwierdzając, czy dana instalacja będzie miała szansę na dotrzymanie wskazanych powyżej terminów. W tym aspekcie należy jeszcze podkreślić, że zgromadzona dokumentacja powinna dotyczyć danej instalacji OZE w rozumieniu art. 2 pkt 13 u.o.z.e. Chodzi tu przede wszystkim o dostateczne wyodrębnienie zarówno pod względem technicznym, jak i prawnym całościowo ujętej instalacji OZE ${ }^{12}$. Przeprowadzenie przez Prezesa URE owego postępowania umożliwia więc wyeliminowanie już na wstępnym etapie tych projektów inwestycyjnych, których realizacja byłaby niemożliwa z powodu niezapewnienia pełnej zgodności inwestycji z przepisami prawa. Dopuszczenie takich projektów do aukcji OZE mogłoby nie tylko zakłócić jej konkurencyjny przebieg, ale również negatywnie wpłynąć na nałożone na Polskę cele wynikające z polityki klimatyczno-energetycznej UE, w tym przede wszystkim wiążące udziały OZE w energii zużywanej brutto w danym państwie członkowskim. Kolejnym ważnym celem realizacji postępowań prekwalifikacyjnych będzie zabezpieczenie podstawowych zasad wsparcia, które może być przeznaczane jedynie na cele związane $\mathrm{z}$ ochroną środowiska. $\mathrm{W}$ ramach omawianych działań chodzi o wspieranie wykorzystania wyłącznie nośników energii kwalifikowanych jako odnawialne źródło energii. W związku z powyższym już na etapie prekwalifikacji wytwórca wykorzystujący do wytwarzania energii elektrycznej biomasę, biogaz, biogaz rolniczy lub biopłyn musi złożyć stosowne oświadczenie, o treści wskazanej w art. 75 ust. 4 pkt 4 albo art. 71 ust. 3 u.o.z.e. Sprowadza się ono do oświadczenia, pod groźbą odpowiedzialności karnej za składanie fałszywych oświadczeń, że wytwórca ten nie będzie wykorzystywał zakazanych albo pełnowartościowych ${ }^{13}$ nośników energii, których wykorzystanie byłoby sprzeczne $\mathrm{z}$ ratio legis ustawy. Zgodnie z art. 84 u.o.z.e. Prezes URE może przeprowadzać kontrolę przestrzegania obowiązków, do których zobowiązał się wytwórca we wskazanym powyżej oświadczeniu. Sankcją za nieprzestrzeganie owych zobowiązań jest zakwalifikowanie kwestionowanej ilości energii elektrycznej jako energii

${ }^{12}$ Zob. A. Frąckowiak, Komentarz do art. 2, w: Ustawa o odnawialnych źródłach energii. Komentarz, pod red. J. Baehra, P. Lissonia, J. Pokrzywniaka, M. Szambelańczyka, Warszawa 2016, s. 42-44.

${ }^{13}$ Zob. treść oświadczenia zawartą w art. 75 ust. 4 pkt 4 u.o.z.e., np. zakaz wykorzystywania paliw kopalnych, drewna pełnowartościowego itp. 
niewytworzonej z odnawialnych źródeł energii, a w konsekwencji także kolejne sankcje płynące $\mathrm{z}$ niedotrzymania zadeklarowanego $\mathrm{w}$ aukcji określonego wolumenu energii elektrycznej. Ponadto postępowanie prekwalifikacyjne niewątpliwie realizuje też niezwykle ważne cele informacyjne. Jednym z celów przeprowadzenia tych postępowań jest zatem również pozyskanie przez Prezesa URE niezbędnych informacji faktycznych, dotyczących projektowanych bądź wybudowanych instalacji OZE. Przedstawiane Prezesowi URE dokumenty zawieraja podstawowe informacje o samym wytwórcy oraz lokalizacji instalacji OZE, co umożliwi sprawdzenie, czy taki podmiot w ogóle może brać udział w aukcji OZE ${ }^{14}$. Dodatkowo wykazane sa parametry techniczne danej instalacji OZE, wskazujące, w ramach której z poszczególnych aukcji wymienionych $w$ art. 73 ust. $3 a \mathrm{w} z w . z$ art. 73 ust. 4 u.o.z.e. będzie konkurowała dana instalacja OZE. Wreszcie przedstawiona dokumentacja powinna wykazywać, że dany wytwórca będzie mógł rzeczywiście rozpocząć wytwarzanie energii w terminie wskazanym $\mathrm{w}$ art. 79 ust. 3 pkt 8 u.o.z.e. W szczególności Prezes URE przeanalizuje potencjalne zagrożenia natury technicznej oraz finansowej, które mogłyby wpłynąć na problemy z finalną realizacją projektu inwestycji w instalację $\mathrm{OZE}^{15}$. Wnikliwość prowadzonych postępowań prekwalifikacyjnych zweryfikuje dopiero praktyczne stosowanie tych przepisów przez organ regulacyjny. Jednakże już teraz można przeanalizować teoretyczny model prowadzenia tego typu postępowań.

\section{Charakter prawny, rodzaje oraz przebieg postępowań prekwalifikacyjnych}

Na tym etapie prowadzonych rozważań należy już przejść do szczegółowego omówienia przepisów prawnych kształtujących podstawowe zasady prowadzenia postępowań prekwalifikacyjnych. Tak jak wielokrotnie wskazywano $\mathrm{w}$ ramach niniejszego opracowania, wytwórcy,

${ }^{14}$ Szerzej na temat zakresu pojęcia wytwórcy OZE zob. E. Kosiński, M. Trupkiewicz, Gmina jako podmiot systemu wspierania wytwarzania energii elektrycznej z odnawialnych źródet energii, „Ruch Prawniczy, Ekonomiczny i Socjologiczny” 2016, z. 3, s. 102-105.

${ }^{15}$ Wytwórca, który wygrał aukcję, zgodnie z art. 83 ust. 1 pkt 1 u.o.z.e. musi też przekazywać Prezesowi URE informacje o stanie wykonania harmonogramu rzeczowego i finansowego w terminie 30 dni od zakończenia każdego roku kalendarzowego. Niedopełnienie tego obowiązku, zgodnie z art. 168 pkt $16 \mathrm{w}$ zw. $\mathrm{z}$ art. 170 ust. 4 pkt 1 u.o.z.e., wiąże się z koniecznością uiszczenia kary pieniężnej w wysokości 10000 zł. 
którzy zamierzają przystąpić do aukcji, z różnym natężeniem podlegają swego rodzaju ocenie możliwości wzięcia udziału w aukcjach OZE, poprzedzającej etap składania oferty aukcyjnej. Przedmiotem takiego postępowania jest ocena możliwości eksploatacji każdej pojedynczej instalacji OZE, która to po ewentualnym wygraniu aukcji w odpowiednich terminach będzie musiała zacząć wytwarzać energię elektryczną zakontraktowaną w aukcji OZE. Generalnie, określając charakter prawny owych postępowań, należy wskazać, że zgodnie z art. 90 ust. 1 u.o.z.e. do postępowań tych stosuje się przepisy Ustawy z dnia 14 czerwca $1960 \mathrm{r}$. Kodeks postępowania administracyjnego ${ }^{16}$. Przepis ten nie pozostawia wątpliwości, że postępowania prekwalifikacyjne mają charakter postępowań administracyjnych, do których przepis k.p.a. stosuje się bezpośrednio, chyba że pewne kwestie proceduralne są inaczej uregulowane $\mathrm{w}$ przepisach u.o.z.e. $\mathrm{W}$ takim przypadku zastosowanie znajduje zasada lex specialis derogat legi generali przyznająca prym stosowaniu przepisów ustawy szczegółowej, jaką w tym zakresie jest u.o.z.e. Jednocześnie należy podkreślić, że jeżeli pewne kwestie nie zostały uregulowane $\mathrm{w}$ przepisach u.o.z.e., to należy wprost stosować właściwe przepisy k.p.a. Postępowania prekwalifikacyjne mogą być inicjowane w trybie ciągłym, co oznacza, że wytwórcy w każdym czasie mogą złożyć do Prezesa URE odpowiednie pisma wszczynające postępowania prekwalifikacyjne. $W$ tym zakresie należy jednak podkreślić, że wytwórcy zamierzający wziąć udział w aukcji OZE powinni rozpoczynać postępowanie $\mathrm{z}$ odpowiednim wyprzedzeniem, a więc $\mathrm{w}$ terminie obiektywnie umożliwiającym jego przeprowadzenie. Co do samego wszczęcia postępowań prekwalifikacyjnych, należy jeszcze dodać, że przepisy u.o.z.e. nie modyfikują generalnych zasad dotyczących formy składania wniosków wszczynających postępowania prekwalifikacyjne. $\mathrm{W}$ związku z powyższym, na podstawie art. $63 \S 1$ k.p.a. mogą być one wnoszone zarówno w tradycyjnej formie pisemnej, jak i przy wykorzystaniu odpowiedniego formularza dostępnego na internetowej platformie aukcyjnej, umożliwiającej Prezesowi URE przeprowadzanie aukcji OZE w środowisku internetowym. Niemniej, jeżeli wytwórca zdecyduje się wszcząć odpowiednie postępowanie prekwalifikacyjne tradycyjnym pismem składanym w formie papierowej, to zgodnie z $\$ 7$ ust. 8 Regulaminu aukcji na sprzedaż energii elektrycznej wytwarzanej w instalacjach OZE (dalej „Regulamin

\footnotetext{
16 Tekst jedn. Dz.U. 2016, poz. 23, dalej „k.p.a.”.
} 
Aukcji"), nie zwalnia go to z obowiązku wysłania tego wniosku także za pośrednictwem platformy internetowej, na której odbywają się aukcje OZE. Chodzi o to, aby pozytywne przejście etapu prekwalifikacji było uwzględnione również na internetowej platformie aukcyjnej, wyłącznie za pośrednictwem której można składać odpowiednie oferty aukcyjne. Jeżeli w systemie informatycznym dana instalacja OZE nie będzie miała wprowadzonych danych potwierdzających prawidłowe przejście etapu prekwalifikacji, wytwórca nie będzie mógł złożyć oferty aukcyjnej dla tej instalacji OZE. Ponadto wszczęcie postępowania w tradycyjnej formie papierowej lub elektronicznej determinuje też konieczność zastosowania odpowiednich podpisów uwierzytelniających treść składanych wniosków. W przypadku pism $\mathrm{w}$ formie papierowej będzie to podpis własnoręczny, a w przypadku pism składanych drogą elektroniczną jeden z podpisów elektronicznych, o których mowa w art. 79 ust. 4 u.o.z.e. Kończąc ogólne rozważania dotyczące zasad prowadzenia postępowań prekwalifikacyjnych, należy wskazać, że ustawodawca przewidział dwa podstawowe rodzaje owych postępowań, które choć w zakresie szczegółowych rozwiązań zasadniczo różnią się od siebie, to jednak ich wspólnym elementem jest to, że każde z nich poprzedza oraz umożliwia wzięcie udziału w aukcji OZE poszczególnym kategoriom wytwórców. W konsekwencji należy jednoznacznie podkreślić, że na podstawie aktualnie obowiązujących przepisów u.o.z.e. nie jest możliwe wzięcie udziału w aukcji OZE bez zrealizowania odpowiedniego postępowania prekwalifikacyjnego. W związku z powyższym dalsza część niniejszego opracowania poświęcona jest omówieniu szczegółowych przepisów prawa regulujących odrębne zasady przeprowadzania owych postępowań prekwalifikacyjnych.

\subsection{Deklaracja o przystąpieniu do aukcji OZE}

Tak jak wskazano powyżej, postępowania poprzedzające udział w aukcji OZE realizowane są w ramach dwojakiego rodzaju postępowań administracyjnych, których zasadność stosowania determinowana jest podmiotowo, a więc ze względu na rodzaj podmiotów chcących wziąć udział w danej aukcji OZE, a także przy uwzględnieniu terminu 1 lipca 2016 r., związanego z wejściem w życie stosownych rozwiązań u.o.z.e. Wprowadzenie tego rodzaju dychotomii w zakresie konieczności wyodrębnienia dwóch rodzajów postępowań umożliwiających wzięcie 
udziału w aukcjach OZE spowodowane jest przede wszystkim stopniowym wypieraniem instrumentu wsparcia opartego na tzw. zielonych certyfikatach przez docelowy model wsparcia oparty na aukcjach OZE. Na tej podstawie wytwórcy, których instalacje OZE po raz pierwszy wytworzyły energię elektryczną przed dniem wejścia w życie rozdziału 4 u.o.z.e. kształtującego nowe mechanizmy i instrumenty wsparcia, tj. przed datą 1 lipca 2016 r., mają prawo wybrać, z jakiego instrumentu wsparcia będą chcieli korzystać. Oznacza to, że wytwórcy ci mogą zdecydować się na pozostanie w systemie „zielonych certyfikatów” bądź też po zrealizowaniu odpowiedniego postępowania prekwalifikacyjnego wziąć udział w danej aukcji OZE, o ile umożliwi im to ilość energii elektrycznej „zamówionej” przez Radę Ministrów w ramach rozporządzenia wydawanego na podstawie art. 72 ust. 1 u.o.z.e. W związku z powyższym podmiotami, które na podstawie złożonej deklaracji mogą wziąć udział w cyklicznie organizowanych aukcjach OZE, są wytwórcy wskazani w art. 71 ust. 1 u.o.z.e. Należy do nich zaliczyć:

1. wytwórców wytwarzających energię elektryczną z OZE w mikroinstalacji, będących przedsiębiorcami w rozumieniu Ustawy z dnia 2 lipca 2004 r. o swobodzie działalności gospodarczej ${ }^{17}$, pod warunkiem, że energia elektryczna została wytworzona w tej mikroinstalacji po raz pierwszy przed dniem 1 lipca 2016 r. albo została zmodernizowana po tej dacie;

2. wytwórców wytwarzających energię elektryczną z OZE w instalacjach OZE innych niż mikroinstalacje pod warunkiem, że energia elektryczna została wytworzona w tych instalacjach OZE po raz pierwszy przed dniem 1 lipca 2016 r. albo zostały one zmodernizowana po tej dacie.

W tym zakresie należy jeszcze podkreślić, że w przypadku zmodernizowanych instalacji OZE do pierwszego wytworzenia energii elektrycznej również musiało dojść już przed dniem 1 lipca 2016 r., po której to dacie instalacja ta podlegała opisanemu w u.o.z.e. procesowi modernizacji. Ponadto w art. 71 ust. 2 u.o.z.e. ustawodawca wskazał dodatkowe przesłanki, które uniemożliwiają złożenie omawianej deklaracji wytwórcom działającym w oparciu o określone w tym przepisie instalacje. Wskazane wyłączenia mają charakter przedmiotowy i dotyczą parametrów technicznych poszczególnych instalacji, które choć produkują energię elektryczną w oparciu o źródła kwalifikowane jako odnawialne, to w oczach ustawodawcy nie powinny uczestniczyć

\footnotetext{
${ }^{17}$ Tekst jedn. Dz.U. 2016, poz. 1829.
} 
w aukcjach OZE. Chodzi przede wszystkim o instalacje spalania wielopaliwowego, duże instalacje (większe niż $50 \mathrm{MW}$ ) wykorzystujące do wytwarzania energii elektrycznej biomasę, biopłyny, biogaz lub biogaz rolniczy z wyłączeniem wysokosprawnej kogeneracji osiągającej moc większą niż 150 MWt lub dedykowanych instalacji spalania wielopaliwowego, a także instalacji o łącznej mocy powyżej 20 MW wykorzystujących hydroenergię. Przykładowo, wytwórca dysponujący instalacją działającą przed 1 lipca 2016 r., o łącznej mocy zainstalowanej elektrycznej większej niż $20 \mathrm{MW}$, wykorzystującą wyłącznie hydroenergię nie może złożyć stosownej deklaracji, a w związku z tym nie będzie mógł brać udziału w organizowanych aukcjach OZE. Stosunkowo łatwo zatem zauważyć, że możliwość złożenia omawianej deklaracji przez danego wytwórcę oprócz przesłanek podmiotowych kwalifikowana jest również przedmiotowo, a więc ze względu na rodzaj instalacji OZE, za pomocą których poszczególni wytwórcy prowadzą swoją działalność. Oznacza to, że o możliwości złożenia deklaracji o przystąpieniu do aukcji OZE przesądzają zarówno przesłanki o charakterze podmiotowym, odnoszące się do samych wytwórców, jak i przedmiotowym, odnoszące się do instalacji OZE, za pomocą których poszczególni wytwórcy prowadzą swoją działalność. Biorąc pod uwagę powyższe ustalenia, należy zatem wskazać, że wytwórcy składający deklarację o przystąpieniu do aukcji powinni precyzyjnie wskazać, z jaką instalacją OZE zamierzają przejść do systemu aukcyjnego wraz z określeniem jej podstawowych parametrów technicznych, umożliwiających weryfikację negatywnych przesłanek opisanych w art. 71 ust. 1 i 2 u.o.z.e. Informacje przekazywane w deklaracji mają również umożliwić weryfikację dotychczasowych koncesji pod względem kryteriów pojęcia instalacji OZE określonych w art. 2 pkt 13 u.o.z.e. Jak wskazuje bowiem Prezes URE, w przypadku niektórych wytwórców niezbędne może się okazać dostosowanie do nowych wymagań u.o.z.e. ${ }^{18}$ Interpretację akcentująca, że deklarację powinno się składać odrębnie dla każdej instalacji OZE, zdaje się również potwierdzać $\& 8$ ust. 1 Regulaminu Aukcji, ustalonego przez Prezesa URE na podstawie art. 78 ust. 9-11 u.o.z.e. Złożenie deklaracji przez podmiot niewskazany $\mathrm{w}$ art. 71 ust. 1 u.o.z.e. lub przy wykorzystaniu instalacji wskazanej w art. 72 ust. 2 u.o.z.e. jest bezskuteczne ze względu na naruszenie wskazanych powyżej przepisów u.o.z.e. Uwzględniając również fakt, że złożenie omawianej deklaracji możliwe jest jedynie

\footnotetext{
${ }^{18}$ Informacja Prezesa Urzędu Regulacji Energetyki z dnia 21 XII 2015 r., s. 1, 4-5.
} 
w przypadku, gdy dana instalacja OZE funkcjonowała już przed dniem 1 lipca 2016 r., wymogi formalne dla tego rodzaju postępowań prekwalifikacyjnych zostały ograniczone do niezbędnego minimum. Oprócz prawidłowego oznaczenia wytwórcy składającego deklarację oraz podania podstawowych parametrów technicznych instalacji OZE w stosownych przypadkach deklaracja powinna być również opatrzona omawianymi już wcześniej oświadczeniami, o których mowa w art. 71 ust. 3 u.o.z.e. Reasumując dotychczasowe rozważania, należy wskazać, że deklaracja o przystąpieniu do aukcji OZE jest jednostronną czynnością prawną, za pomocą której dany wytwórca deklaruje chęć wzięcia udziału w aukcji OZE, co w konsekwencji umożliwi mu zgłoszenie oferty na wytwarzanie energii elektrycznej w jednej z funkcjonujących przed datą 1 lipca 2016 r. instalacji OZE. Choć dla swojej skuteczności deklaracja nie wymaga formalnej zgody ze strony Prezesa URE, to należy pamiętać, że wskazane w niej dane powinny umożliwić wyodrębnienie takich instalacji OZE, które w świetle art. 71 ust. 1 i 2 u.o.z.e. umożliwią "przejście” danego wytwórcy do nowego systemu aukcji OZE ${ }^{19}$. W tym zakresie należy wskazać, że Prezes URE weryfikuje spełnienie ustawowych warunków wskazanych w art. 71 ust. 1, 2 i 3 u.o.z.e., które w przypadku ich niedotrzymania powodują bezskuteczność złożonej deklaracji. Tym samym wytwórca, wyrażając chęć wzięcia udziału w aukcji OZE, pośrednio decyduje również o preferowanym przez siebie modelu pomocy publicznej, z którego korzystać będzie energia wytwarzana przez tę instalację OZE. Zgodnie bowiem z art. 80 ust. 9 pkt 2 u.o.z.e., jeżeli wytwórca, który złożył deklarację, wygra daną aukcji OZE, przestaje korzystać ze wsparcia w formie wydawanych świadectw pochodzenia i najpóźniej pierwszego dnia miesiąca następującego po upływie miesiąca od miesiąca, w którym nastąpiło zamknięcie aukcji, korzysta on już z rozwiązań nowego systemu aukcyjnego. Uzyskana wcześniej pomoc publiczna, w szczególności ta pochodząca ze wskazanych świadectw pochodzenia, tzw. zielonych certyfikatów, będzie musiała być wkalkulowana w cenę oferowaną w ramach aukcji OZE, tak aby nie przekroczyła odpowiedniego poziomu dopuszczalnej pomocy publicznej obliczanej na podstawie art. 39 ust. 1 u.o.z.e. oraz poziomu ceny referencyjnej, o której mowa $\mathrm{w}$ art. 77 ust. 1 u.o.z.e. ${ }^{20}$

${ }^{19}$ J. Pokrzywniak, Komentarz do art. 71, w: Ustawa o odnawialnych źródłach energii..., s. 196.

${ }^{20}$ Szerzej zob. M. Trupkiewicz, M. Tarka, Sposób kalkulacji aukcyjnych cen energii z OZE, „Czysta Energia” 2016, nr 1, s. 16-18. 


\subsection{Zaświadczenie o dopuszczeniu do aukcji OZE}

Do drugiego rodzaju postępowań prekwalifikacyjnych należy zaliczyć postępowania o wydanie zaświadczenia o dopuszczeniu do udziału w aukcji OZE. Postępowania te polegają na formalnej ocenie przez Prezesa URE przygotowania danego projektu instalacji OZE do wytwarzania energii elektrycznej w terminach wskazanych w art. 79 ust. 3 pkt 8 lit. a u.o.z.e., w ramach udostępnionej dokumentacji inwestycyjnej. Procedurę oceny formalnej, zgodnie $z$ art. 75 ust. 3, przeprowadza Prezes URE na wniosek wytwórcy o wydanie zaświadczenia o dopuszczeniu do udziału w aukcji OZE, którego otrzymanie umożliwia mu złożenie oferty w ramach aukcji OZE. W tym zakresie należy wskazać, że przepisy dotyczące postępowania w zakresie wydania zaświadczenia o dopuszczeniu do udziału $\mathrm{w}$ aukcji OZE stanowią lex specialis w stosunku do uregulowań art. 217-220 k.p.a. Jak wskazuje się w doktrynie, zaświadczenie należy traktować jako czynność faktyczną stanowiącą urzędowo potwierdzone oświadczenie wiedzy organu administracji, a więc określonych faktów lub stanu prawnego, lecz oczywiście nie kreuje ono tych faktów ani następstw prawnych ${ }^{21}$. Niemniej ustawodawca pozostawił organowi regulacyjnemu pewien zakres władzy dyskrecjonalnej, wskazując, że Prezes URE w terminie 30 dni od dnia złożenia takiego wniosku wydaje zaświadczenie o dopuszczeniu do aukcji OZE bądź odmawia jego wydania. $W$ art. 75 ust. 2 u.o.z.e. ustawodawca wskazał, że postępowanie umożliwiające wzięcie udziału w aukcji OZE poprzedzone oceną formalna, o której mowa w art. 75 ust. 1 u.o.z.e., nie dotyczy podmiotów, które mogą złożyć deklarację o przystąpieniu do aukcji OZE, w oparciu o instalacje OZE wytwarzające energię elektryczną przed 1 lipca 2016 r. W związku z powyższym obowiązek uzyskania zaświadczenia o dopuszczeniu do udziału w aukcji OZE będzie dotyczył wszystkich wytwórców, którzy zamierzają wziąć udział w takich aukcjach przy wykorzystaniu nowo projektowanych instalacji OZE. Oznacza to, że omawianej procedurze oceny formalnej podlegać będą jedynie projekty instalacji OZE, które z ekonomicznego punktu widzenia powinny zostać wybudowane dopiero po wygraniu aukcji OZE, a więc gdy poszczególni wytwórcy będą mieli już zapewnione operacyjne wsparcie prowadzonej działalności gospodarczej.

${ }^{21}$ K. Celińska-Grzegorczyk, Komentarz do art. 217 KPA, w: Kodeks postępowania administracyjnego. Komentarz, pod red. R. Hausera, M. Wierzbowskiego, Legalis/el. 
Konsekwencją powyższej regulacji jest to, że wytwórca, planując wystartować w akcji OZE, nie musi faktycznie dysponować działającą instalacją OZE, ale może ją wybudować dopiero po wygraniu aukcji. Dodatkowo w przypadku przegranej aukcji, a w konsekwencji braku uzyskania wsparcia, dany wytwórca nie musi w ogóle budować takiej instalacji. Niemniej jeżeli dany wytwórca wybudował już swoją instalację OZE przed datą organizowanej aukcji OZE i będzie chciał wziąć w niej udział, to również będzie musiał przejść etap prekwalifikacji i uzyskać zaświadczenie o dopuszczeniu do udziału w aukcji OZE. W doktrynie wskazuje się, że konieczność przejścia postępowania prekwalifikacyjnego, pomimo wcześniejszego zrealizowania przedmiotu postępowania (instalacji OZE), może mieć charakter potwierdzający skuteczne ukończenie inwestycji, zgodnie z właściwymi przepisami prawa $^{22}$, co umożliwi niezwłoczne przystąpienie do eksploatacji tych urządzeń w odpowiednich terminach wskazanych w art. 79 ust. 3 pkt 8 lit. a u.o.z.e. Postępowania prekwalifikacyjne polegające na wydaniu zaświadczenia o dopuszczeniu do udziału w aukcji OZE inicjowane są złożeniem przez wytwórcę wniosku, który zawiera dane wskazane w art. 75 ust. 4 u.o.z.e. Wydaje się, że ustawowy obowiązek podania w takim wniosku adresu zamieszkania albo adresu siedziby wytwórcy, a także lokalizacji planowanej instalacji OZE ma przede wszystkim zweryfikować, czy dany podmiot spełnia wszystkie przesłanki definicyjne pojęcia wytwórcy wskazanego w art. 2 pkt 39 u.o.z.e., a przez to czy podmiot wszczynający postępowanie może być podmiotem korzystającym z aukcyjnego modelu wsparcia OZE. Przepisy te niewątpliwie realizują opisane w poprzedniej części niniejszego opracowania informacyjne cele postępowań prekwalifikacyjnych. Ponadto, tak jak już wskazywano w przypadku instalacji OZE wykorzystujaccych do wytwarzania energii elektrycznej biomasę, biogaz, biogaz rolniczy lub biopłyny, wniosek powinien być uzupełniony odpowiednim oświadczeniem, o którym mowa w art. 75 ust. 4 pkt 4 u.o.z.e. Dodatkowo poszczególni wytwórcy, chcąc potwierdzić prawidłowość przygotowania projektu instalacji OZE, muszą dołączyć do omawianego wniosku odpowiedni wykaz dokumentów inwestycyjnych. Zgodnie z art. 75 ust. 5 u.o.z.e. dokumentami wymaganymi od nowo projektowanych instalacji OZE są oryginały lub poświadczone kopie: dokumentu

${ }^{22}$ Zob. J. Pokrzywniak, Komentarz do art. 75, w: Ustawa o odnawialnych źródłach energii..., s. 220. 
potwierdzającego dopuszczalność lokalizacji ${ }^{23}$, prawomocnego pozwolenia na budowę, harmonogramu rzeczowego i finansowego albo oświadczenia o zrealizowaniu inwestycji oraz - w zależności od stadium inwestycji - umowy przyłączeniowej albo warunków przyłączenia ${ }^{24}$ projektowanej instalacji OZE do sieci elektroenergetycznej, a w przypadku inwestycji w morskie farmy wiatrowe dodatkowo także prawomocnej decyzji o środowiskowych uwarunkowaniach. W tym aspekcie na szczególną uwagę zasługuje fakt, że w stosunku do niektórych wymienionych powyżej dokumentów, szczegółowo wskazanych w art. 75 ust. 6 u.o.z.e., okres ich ważności w dniu ich złożenia nie może być krótszy niż 6 miesięcy. W tym zakresie $\mathrm{w}$ doktrynie podkreśla się, że pojęcie "okresu ważności” w stosunku do decyzji administracyjnych oraz warunków przyłączenia nie jest pojęciem precyzyjnym, a weryfikacja spełnienia powyższego wymogu będzie wymagać złożenia przez wytwórcę dodatkowych wyjaśnień, jako że spełnienie tego obowiązku nie wynika wprost z treści odpowiednich decyzji administracyjnych ${ }^{25}$. Ponadto, w przypadku decyzji, o których mowa w art. 75 ust. 5 pkt 3 i 4 u.o.z.e., ustawodawca wymaga, aby dołączane do wniosku decyzje administracyjne charakteryzowały się przymiotem prawomocności. Decyzja staje się prawomocna jedynie wówczas, gdy strona postępowania administracyjnego nie może jej zaskarżyć do sądu administracyjnego. Dzieje się tak chociażby wtedy, gdy strona nie wniosła w 30-dniowym terminie skargi do wojewódzkiego sądu administracyjnego albo gdy sąd ten rozstrzygną już daną sprawę, utrzymując decyzję w mocy ${ }^{26}$. Tak

${ }^{23}$ Chodzi zatem o jeden z poniższych dokumentów: wypis i wyrys z miejscowego planu zagospodarowania przestrzennego albo decyzja o warunkach zabudowy i zagospodarowania terenu albo prawomocnego pozwolenia na wznoszenie i wykorzystywanie sztucznych wysp, konstrukcji i urządzeń w polskich obszarach morskich dla przedsięwzięć zlokalizowanych w wyłącznej strefie ekonomicznej.

${ }^{24} \mathrm{~W}$ zakresie zasad przyłączania instalacji OZE do sieci elektroenergetycznej zob. J. Pokrzywniak, Przyłaczanie odnawialnych źródeł energii do sieci elektroenergetycznych po nowelizacji ustawy Prawo energetyczne z dnia 26 lipca 2013 r., w: Inwestycje infrastrukturalne i ochrona środowiska w prawie energetycznym, pod red. K. Ziemskiego, P. Lissonia, Poznań 2014, s. 111-122.

${ }^{25}$ Zob. S. Urban, Komentarz do art. 75, w: Ustawa o odnawialnych źródłach energii..., s. 221-224; w zakresie warunków przyłączenia do sieci elektroenergetycznej zob. J. Pokrzywniak, Umowa o przyłaczenie do sieci elektroenergetycznej, gazowej lub ciepłowniczej oraz obowiazek jej zawarcia, Warszawa 2013, s. 117-122.

${ }^{26} \mathrm{~W}$ orzecznictwie sądowym przymiot prawomocności przypisuje się tylko takim decyzjom, które zostały utrzymane w mocy przez sąd administracyjny albo nie zostały zaskarżone w ustawowym terminie. Zob. postanowienie Naczelnego Sądu 
więc uwzględniając jedynie wykładnię językową, wydaje się, że przepisy u.o.z.e. łączą określone skutki prawne dopiero z decyzją prawomocną, a nie ostateczna, o której mowa w art. 16 § 1 k.p.a. Niemniej w tym aspekcie uwzględnienia wymaga jeszcze dyspozycja art. 269 k.p.a., która wskazuje, że decyzje określane w innych przepisach prawa jako prawomocne uważa się za ostateczne, chyba że z przepisów tych wynika, iż dotyczą one takiej decyzji, która została utrzymana w mocy $\mathrm{w}$ postępowaniu sądowym bądź też nie została zaskarżona $\mathrm{w}$ tym postępowaniu z powodu upływu terminu do wniesienia skargi. W doktrynie wskazuje się, że ustawodawca używa pojęcia prawomocności decyzji administracyjnej jako synonimu decyzji ostatecznej albo pojęcie to używane jest dla związania określonych skutków prawnych - z reguły dla zapewnienia zwiększonego stopnia ochrony interesów prawnych strony lub bezpieczeństwa obrotu - z cechą prawomocności decyzji, tzn. z faktem, że dana decyzja została utrzymana w mocy $\mathrm{w}$ postępowaniu sądowym albo $\mathrm{z}$ niezaskarżeniem $\mathrm{z}$ powodu upływu terminu do wniesienia skargi ${ }^{27}$. Na tym etapie stosowania norm prawnych zawartych w art. 75 ust. 5 u.o.z.e. trudno jednoznacznie wskazać, którym rozumieniem pojęcia prawomocności posłużył się $\mathrm{w}$ tym wypadku ustawodawca. Zdaniem autora można znaleźć argumenty wskazujące, że z przepisów u.o.z.e., mających na celu jak najszybsze uruchomienie instalacji OZE, wynika podwyższony stopień ochrony interesów prawnych stron postępowań inwestycyjno-budowlanych poszczególnych instalacji OZE. W konsekwencji wydaje się, że ustawodawca powiązał określenie analizowanych decyzji jako prawomocnych z ich utrzymaniem w mocy w przypadku postępowań sądowych bądź też z upływem terminu do ich zaskarżenia w takim postępowaniu. Przyjęcie odmiennej koncepcji kłóciłoby się z podstawowym celem postępowania prekwalifikacyjnego umożliwiającego jak najszybsze przystąpienie do eksploatacji projektowanej instalacji OZE, co byłoby znacząco utrudnione, jeżeli w stosunku do danej instalacji OZE toczyłby się nierozstrzygnięty spór sądowo-administracyjny. W pozostałych przypadkach zakres oraz sposób oceny formalnej większości wskazanych powyżej dokumentów nie powoduje trudności, gdyż są one szczegółowo opisane we właściwych przepisach prawa. Dodatkowe wątpliwości nasuwają się jedynie w przypadku harmonogramu rzeczowego

Administracyjnego z 8 III 2000 r., sygn. SA/Rz 2073/99, „Palestra” 2001, nr 5-6, s. 211; por. R.A. Rychter, Res iudicata w postępowaniu administracyjnym, Warszawa 2014, s. 65-70.

${ }^{27}$ K. Gilbowski, Komentarz do art. 269 KPA, w: Kodeks postępowania administracyjnego... 
i finansowego dotyczącego realizacji lub modernizacji danej instalacji OZE. Wytwórca jest zatem zobowiązany dostarczyć organowi regulacyjnemu odpowiednie informacje dotyczące źródeł finansowania projektu oraz aspektów jego technicznej realizacji. Niemniej przepisy u.o.z.e. nie przewidują żadnych kryteriów, którymi powinien kierować się Prezes URE, weryfikując, czy wskazane w harmonogramie dane uzasadniają dotrzymanie terminów wskazanych w art. 79 ust. 3 pkt 8 lit. a u.o.z.e. Prezes URE dyskrecjonalnie ocenia zatem, czy przedstawione $\mathrm{w}$ harmonogramie dane rzeczywiście pozwalają na wybudowanie danej instalacji, choć nie ma kompetencji do kwestionowania lub szczegółowego badania poziomu przedstawianych kosztów bądź zabezpieczenia odpowiednich źródeł finansowania. Niemniej już na tym etapie Prezes URE może zidentyfikować te projekty instalacji OZE, które będą korzystały z jakiejkolwiek innej formy pomocy publicznej przy finansowaniu przedmiotowej inwestycji, która to pomoc będzie musiała zostać rozliczona zgodnie z dyspozycją art. 39 u.o.z.e. Niezależnie od przedstawionych wątpliwości dotyczących charakteru oraz treści załączanych do wniosku dokumentów Prezes URE przed wydaniem zaświadczenia o dopuszczeniu do aukcji OZE przeprowadza w tym zakresie postępowanie wyjaśniające. Analizuje on przedstawione mu informacje natury technicznej i finansowej oraz dokonuje swego rodzaju audytu prawnego dokumentacji potrzebnej do przeprowadzenia inwestycji w instalację OZE. Pozytywne albo negatywne rozstrzygnięcie w kwestii wydania zaświadczenia Prezes URE podejmuje w terminie 30 dni od dnia złożenia wniosku o wydanie tego zaświadczenia, choć wskazany w tym przepisie termin należy uznać za termin instrukcyjny. W przypadku pozytywnego rozstrzygnięcia Prezesa URE i wydania odpowiedniego zaświadczenia o dopuszczeniu do aukcji OZE termin jego ważności wynosi jedynie 12 miesięcy, liczonych od dnia wydania tego zaświadczenia. Wyjątkiem w tym zakresie jest uzależnienie ważności zaświadczenia od terminu ważności odpowiednich dokumentów, wskazanych w art. 76 ust. 4 u.o.z.e. Tak więc co do zasady procedurę prekwalifikacji trzeba będzie powtórzyć, jeżeli dany projekt inwestycyjny nie uzyska wsparcia w ramach jednej z aukcji OZE, a wytwórca będzie chciał zgłosić kolejną ofertę w następnych aukcjach przeprowadzanych w kolejnych latach. Natomiast odmowa wydania omawianego zaświadczenia następuje $\mathrm{w}$ formie postanowienia, na które służy zażalenie. Zgodnie z art. 76 ust. 3 u.o.z.e. zażalenie to wnosi się do Sądu Okręgowego w Warszawie - sądu ochrony konkurencji i konsumentów, 
w terminie 7 dni od dnia doręczenia postanowienia o odmowie wydania zaświadczenia o dopuszczeniu do udziału w aukcji. Należy tu podkreślić, że brak specjalnego trybu rozpatrywania takich zażaleń może w praktyce uniemożliwić uzyskanie omawianego zaświadczenia przez wytwórcę, a w konsekwencji uniemożliwić mu wystartowanie w ramach organizowanej aukcji OZE. Wytwórca, uzyskując takie zaświadczenie po rozstrzygnięciu danej aukcji OZE, na podstawie uzyskanego dokumentu będzie mógł wziąć udział dopiero w kolejnych aukcjach organizowanych w okresie ważności omawianego zaświadczenia. W tym zakresie de lege ferenda należałoby postulować wprowadzenie specjalnego, przyspieszonego trybu rozpatrywania zażaleń na postanowienia o odmowie wydania zaświadczenia o dopuszczeniu do udziału w aukcji OZE. Czas potrzebny na przeprowadzenie postępowania sądowego w praktyce może uniemożliwić danemu wytwórcy wzięcie udziału w aukcji OZE organizowanej co do zasady przynajmniej raz w roku kalendarzowym. Choć dotychczas przed sądem nie zawisł żaden spór w takiej sprawie, to z praktyki znane są już przypadki, w których Prezes URE nie wydał w terminie 30 dni odpowiednich zaświadczeń wszystkim zainteresowanym podmiotom przed zorganizowaniem aukcji, co w konsekwencji uniemożliwiło im skuteczne zgłoszenie oferty aukcyjnej. Podobne zagrożenie można dostrzec także w przypadku sporu co do odmowy wydania zaświadczenia o dopuszczeniu do aukcji OZE.

\section{Podsumowanie}

Przeprowadzone rozważania pozwalają na stwierdzenie, że wytwórcy dysponujący opisanymi w niniejszym opracowaniu instalacjami OZE mogą wziać udział w aukcji OZE dopiero po przeprowadzeniu odpowiedniego rodzaju postępowania prekwalifikacyjnego. Instrument ten ma umożliwić niezwłoczne przystąpienie do wytwarzania energii

elektrycznej w terminach wskazanych w art. 79 ust. 3 pkt 8 u.o.z.e. Postępowania te mają zatem charakter ex ante, co ma na celu, aby jeszcze przed dopuszczeniem poszczególnych wytwórców do aukcji OZE wyeliminować tych, którzy z różnych przyczyn mogliby nie zrealizować złożonych przez siebie projektów albo nie dotrzymaliby wskazanych powyżej terminów. Tak więc postępowanie prekwalifikacyjne tworzy swego rodzaju wstępny etap poprzedzający same aukcje OZE, którego pozytywne przejście determinuje możliwość faktycznego uczestnictwa 
w jednej z wybranych aukcji OZE. Innymi słowy, nie jest możliwe wzięcie udziału w aukcji OZE bez prawidłowego zrealizowania odpowiedniego postępowania prekwalifikacyjnego, polegającego na złożeniu deklaracji o przystąpieniu do aukcji OZE bądź uzyskaniu zaświadczenia o dopuszczeniu do aukcji OZE. Ustawodawca, konstruując przepisy dotyczące postępowań prekwalifikacyjnych, już na wstępnym etapie uczestnictwa w systemie wsparcia dąży do wyeliminowania projektów fikcyjnych, a więc takich, których inwestorzy w ogóle nie mają zamiaru zrealizować, manipulując w ten sposób przebiegiem oraz rozstrzygnięciami płynącymi z aukcji OZE ${ }^{28}$. Niezrealizowane projekty instalacji OZE wyłonione $w$ ramach aukcji OZE w szczególności nie przyczynią się do osiągnięcia celów polityki klimatyczno-energetycznej UE, która przewiduje $15 \%{ }^{29}$ udziału OZE w końcowym zużyciu energii brutto w Polsce w 2020 r. Chodzi tu o projekty instalacji OZE, które choć teoretycznie mogłyby wygrać aukcję, to w rzeczywistości nie mogłyby wytwarzać energii elektrycznej z OZE we wskazanym przez ustawę terminie. W szczególności mowa tu o przeszkodach natury prawnej (np. brak odpowiednich decyzji administracyjnych), technicznej (np. rodzaj wykorzystywanego źródła energii) czy finansowej (np. niedoszacowania przewidzianych wydatków inwestycyjnych).

Ponadto w trakcie postępowania Prezes URE uzyskuje niezbędne informacje dotyczące wytwórcy oraz samej instalacji OZE. Organ regulacyjny sprawdza, czy podmiot ten można zakwalifikować jako wytwórcę w rozumieniu art. 2 pkt 39 u.o.z.e. oraz czy postępowanie dotyczy całościowo ujętej i dostatecznie wyodrębnionej pod względem prawnym i technicznym instalacji OZE, o której mowa w art. 2 pkt 13 lit. a u.o.z.e. W przypadku braku postępowań prekwalifikacyjnych projekty te mogłyby blokować innym wytwórcom możliwość uzyskania wsparcia w ramach rządowych limitów „zakontraktowanej” energii z OZE oraz ograniczałyby moce przyłączeniowe na poszczególnych odcinkach sieci elektroenergetycznej.

${ }^{28} \mathrm{~W}$ ograniczonym zakresie chodzi też o zminimalizowanie zjawiska określanego jako underbidding, a więc oferowania w aukcjach zaniżonych cen, nieprzystających do rzeczywistych kosztów projektowanej instalacji OZE. Szerzej zob. W. Szopiński, Wady i zalety przyjętych rozwiazań prawnych dotyczacych aukcji na wytwarzanie energii elektrycznej ze źródeł odnawialnych, http://www.cire.pl/item,129531,2,1,2,0,290038,0,wady-i-zaletyprzyjetych-rozwiazan-prawnych-dotyczacych-aukcji-na-wytwarzanie-energii-elektrycz nej-ze-zrodel-odnawialnych.html\#komentarz (dostęp: 17 I 2017).

${ }^{29}$ Zob. Załącznik I do dyrektywy 2009/28/WE Krajowe cele ogólne w zakresie udziału energii ze źródeł odnawialnych w końcowym zużyciu energii brutto w 2020 r. 
Podkreślenia wymaga również to, że ustawodawca wyodrębnił dwa rodzaje postępowań prekwalifikacyjnych, które choć realizują wspólne cele wyinterpretowane z przepisów u.o.z.e., to jednak różnią się w zakresie szczegółowych uregulowań prawnych, kształtujących oba te postępowania warunkujące udział w aukcji OZE. Wytwórcy wyodrębnieni na podstawie przesłanek podmiotowo-przedmiotowych, którzy uruchomili swoje instalacje przed dniem 1 lipca 2016 r., będą mogli złożyć deklarację o przystąpieniu do aukcji OZE, natomiast pozostali wytwórcy, którzy chcą uruchomić swoje instalacje po tej dacie, będą musieli uzyskać odpowiednie zaświadczenie o dopuszczeniu do udziału w aukcji OZE. Co do zasady należy również wskazać, że postępowania polegające na złożeniu deklaracji, a więc stosownego oświadczenia o przystąpieniu do aukcji OZE, są mniej rygorystyczne w tym znaczeniu, że nie wymagają one złożenia dodatkowej dokumentacji inwestycyjnej podlegającej sprawdzeniu $\mathrm{w}$ toku postępowania prowadzonego przez Prezesa URE. Wprowadzenie owych uproszczeń natury formalnej wydaje się tym bardziej uzasadnione, że będące przedmiotem danej deklaracji instalacje OZE są już eksploatowane, a prowadzone w tym zakresie postępowanie prekwalifikacyjne ma jedynie potwierdzić zasadność uczestnictwa danego przedsięwzięcia w systemie aukcji OZE. Natomiast wytwórcy, którzy nie uruchomili swoich instalacji OZE przed dniem 1 lipca 2016 r., muszą przejść bardziej rygorystyczną procedurę oceny formalnej przygotowania do wytwarzania energii elektrycznej w danej instalacji OZE, dodatkowo obciążoną koniecznością złożenia odpowiedniej dokumentacji inwestycyjnej, szczegółowo opisanej w art. 75 ust. 5 u.o.z.e. Niemniej niezależnie od wprowadzonych powyżej rozróżnień wszyscy wytwórcy planujący udział w aukcji OZE powinni odpowiednio wcześniej rozpocząć właściwe postępowanie prekwalifikacyjne dotyczące każdej instalacji OZE oraz uwzględnić czas potrzebny na jego przeprowadzenie oraz rozstrzygnięcie ewentualnych sporów sądowych. Niedoszacowanie terminów lub nieprawidłowe przygotowanie pism wszczynających odpowiednie postępowanie prekwalifikacyjne może uniemożliwić im udział w zaplanowanej w danym roku aukcji OZE. 


\section{THE PRE-QUALIFICATION PROCEEDING AS THE FIRST STAGE OF THE RENEWABLE ENERGY SOURCES AUCTION}

\section{S u m m a ry}

The paper describes the legal grounds of prequalification proceedings allowing certain categories of energy producers to participate in the Polish auction system, and thus to create a new system responsible for supporting the development of renewable energy sources (RES). These procedures are of administrative proceedings character but are modified by specific legal provisions under the RES regulations. The legislator differentiated between two types of these procedures. Although they differ in specific legal provisions, they both pursue to achieve common targets that will subsequently contribute to a speedy development of the RES plants in Poland. Among the main objectives of the prequalification proceeding, the necessity of the regulatory authority to obtain the basic information about the RES installation project must be mentioned. This information not only allows to check the legitimacy of the accession to the RES auctions system but also allows to check the investment documentation of the project, and consequently implement and start the RES installation on time as prescribed by the law. In the initial period, the measures taken by the RES are to be aimed at eliminating form the auction these energy producers who could theoretically win the RES auction but would not, due to legal, technical or financial reasons manage to complete the investment (build and start up the RES installation) within the time prescribed. This would not only impede a competitive conduct of the RES auction but would also prevent realisation of the EU climate and energy policy due to the failure to produce enough electricity to meet the required volume contracted for each new RES installations according the RES auctions.

Keywords: RES supporting system - RES auctions - prequalification procedures 